\title{
Editorial Board Thoughts: Rise of the Innovation Commons
}

\section{Tod Colegrove}

That the practice of libraries and librarianship is changing is an understatement. Throughout their history, libraries have adapted and evolved to better meet the needs of the communities served. From content collected and/or archived, to facilities and services provided, a constant throughout has been the adoption, incorporation, and eventual transition away from technologies along the way: clay tablets and papyrus scrolls giving way to the codex; the printing press and eventual mass production and collection of books yielding to Information Communication Technology such as computer workstations and the Internet. Indeed, the rapid and widespread adoption of the Internet has enabled entire topologies of information to change - morphing from ponderous print tomes into digital databases, effectively escaping the walls of libraries and archives altogether. ${ }^{1}$

In reflection of end-users' growing preference for easily accessible digital materials, libraries have responded with the creation of new spaces and services. Repositioning physical, digital, human, and social resources to better meet the needs of the communities supported, the information commons ${ }^{2}$ that is the library begins to acquire a more technological edge. The concept of a library service or area referred to specifically as an information commons can be traced to as early as 1992 with the opening of the Information Arcade at the University of Iowa - specifically designed to provide end-users technology tools, with a stated mission "to facilitate the integration of new technology into teaching, learning, and research, by promoting the discovery of new ways to access, gather, organize, analyze, manage, create, record, and transmit information." 3

First mentioned in the literature in 1994, discussion of the idea itself waited another five years, with Donald Beagle writing about the theoretical underpinnings of "the new service delivery model" in 1999. Defined as "a cluster of network access points and associated IT tools situated in the context of physical, digital, human, and social resources organized in support of learning." A flurry of articles followed, with the idea seeming to have caught the collective imagination of libraries generally by 2004. Information commons as named spaces within libraries made "... sudden, dramatic, and widespread appearance in academic and research libraries across the country and around the world." ${ }^{4}$ Scott Bennett went further, in 2008 asking flatly: "who would today build or renovate an academic library without including an information commons?"5

This proliferation and transition has not been limited to academic libraries; for decades, libraries of all type, shape, and size, have been similarly provisioning resources and

Patrick “Tod" Colegrove (pcolegrove@unr.edu), a member of the ITAL Editorial Board, is Head of the DeLaMare Science \& Engineering Library at the University of Nevada, Reno, NV. 
technology in the context of end-user access and learning. By 2006, a new variation of the information commons had entered the vernacular: the learning commons. Defined by Beagle as the result of information commons resources "organized in collaboration with learning initiatives sponsored by other academic units, or aligned with learning outcomes defined through a cooperative process." ${ }^{\prime A}$ A subset of the broader concept, when the library collaborates with stakeholders external to the library to collaboratively achieve academic learning outcomes, it becomes operationally a learning commons. One can easily conceive of the learning commons more broadly by considering learning outcomes desirable within the context of particular library types: school libraries with offerings and programs in alignment with broader K-12 curricula; public libraries in support of lifelong learning and participatory citizenship; special libraries in alignment with other niche-specific learning outcomes.

Note that not all information commons are learning commons. As defined, the learning commons depends on the actions and involvement of other units that establish the mission, and associated learning goals, of the institution. Others must join with the library's effort in order to create and nourish such spaces in a way that is deeply responsive to the aspirations of the institution: "the fundamental difference between the information and the learning commons is that the former supports the institutional mission while the latter enacts it." (Bennett 2008, emphasis added) At a time when libraries are undergoing such rapid and significant transformation, it's hard to dismiss such collaborative effort as merely trendy such spaces, and the library by extension, become of even more fundamental relevance to the broader organization.

In short, resources are provisioned in the information commons so that learning can happen; collaborative effort with stakeholders beyond the library, but within the organization, ensures that learning does happen.

Drawing a parallel, what if the library were to go beyond simply repositioning resources in support of learning - indeed, beyond working with other units of the organization to collaboratively align and provision resources in support of achieving organizational learning outcomes? To go beyond strategic alignment with the aspirations of the institution, involving stakeholders from beyond the immediate organization in the creation and support of such spaces? Provisioning library spaces and services that are deeply responsive to the aspirations of the greater community? Arguably this is where the relatively recent introduction of makerspaces into the library fits in. The annual environmental scan performed by the New Media Consortium (NMC) has for a number of years identified makerspaces to be on its short-term adoption horizon - the 2015 Library Edition goes further, identifying a core value:

the introduction of makerspaces in the academic library is inspiring a mode of learning that has immediate applications in the real world. Aspiring inventors and entrepreneurs are 
taking advantage of these spaces to access tools that help them make their dreams into concrete products that have marketable value. ${ }^{7}$

Aspects of the information commons are present in library makerspace - not only in the access to traditional library resources, but also in the shift toward providing support of 21stcentury literacies in the creation, design, and engineering of output. With the acquisition and use of these literacies in collaboration with and in support of the goals of the greater institution, it is also a learning commons; for example, in the case of a school or public library where makerspace activities and engagement collaboratively meet and support learning outcomes including increased engagement with Science, Technology, Engineering, the Arts, and Math (STEAM) disciplines. Consider the further example of university students leveraging makerspace technology as part of STE(A)M outreach efforts to local middle schools in the hope of kindling interest, or partnering with the local Discovery Museum in the production of a mini maker-faire to carry that interest forward. Alternatively, a team of students conceiving, then prototyping and patenting a new technology with the active and direct support of the library commons, going on to eventually launch as a business. To the extent the library can springboard off the combination of makerspace with information or learning commons to engage stakeholders from beyond the institution, it can go beyond becoming something broader, and potentially transformative; even as it enables progress toward collaboratively achieving community goals, outcomes, and aspirations.

The hallmark of community engagement with such library facilities is a spontaneous innovation that seems to flow naturally. Library? Information or learning commons? Arguably such spaces are more accurately named innovation commons.

Beyond solidifying the library's place as a hub of access, creation, and engagement across disciplinary and organizational boundaries, the direct support of innovation - the process of going from idea to an actual good or service with a real perceived value - is in potential alignment with the aspirations of the broader community. In collaboration with stakeholders from across the community, from economic development and government representatives to businesses and private individuals, broader outcomes and aspirations of the greater community can be identified and supported. Nevertheless, simply adding makerspace technology to an information or learning commons does not automatically create an innovation commons. It is in the broader conversation, along with the catalyzation, identification of and support for the greater aspirations of the community, that the commons begins to assume its proper role in the greater ecosystem. Leveraging the deliberate application of information, with imagination, and initiative, enabling end-users to go from idea all the way to useful product or service is something that community stakeholders see as a tangible value. 
The library as innovation commons becomes a natural partner in the local innovation ecosystem, working collaboratively to achieve community aspirations and economic impact. Traditional business and industry reference support ramps up to another level, providing active and participatory support of coworking, startup companies, and Etsypreneur ${ }^{8}$ alike patent searches taking on an entirely new light in support of innovators using makerspace resources to rapidly prototype inventions. Actualized, the library joins forces in a deeper way with the community in the creation of new technologies, jobs, and services, taking an ever more active role in building the futures of the community and its members.

\section{REFERENCES}

1. Morgan Currie, "What We Call the Information Commons," institute of network cultures blog, July 8, 2010, http://networkcultures.org/blog/2010/07/08/what-we-call-theinformation-commons/

2. The word commons reflects the shared nature of a resource held in common, such as grazing lands.

3. Robert A. Seal, "Issue Overview," Journal of Library Administration, 50 (2010), 1-6. http://www.tandfonline.com/doi/pdf/10.1080/01930820903422248

4. Charles Forrest \& Martin Halbert, A field guide to the Information Commons. Lanham, MD: Scarecrow, 2009.

5. Scott Bennett, “The Information or the Learning Commons: Which Will We Have?," The Journal of Academic Librarianship, 34, no. 3 (2008), 183-185.

6. Donald Robert, Donald Russel Bailey, \& Barbara Tierney, The Information Commons Handbook, xviii. New York: Neal Schuman, 2006.

7. Larry Johnson, Samantha Adams Becker, Victoria Estrada, and Alex Freeman, NMC Horizon Report: 2015 Library Edition, 36. Austin, TX: The New Media Consortium, 2015.

8. The combination of Etsy, a peer-to-peer e-commerce website that focuses on selling handmade, vintage, or unique items, and entrepreneurship. The word "Etsypreneur" refers to someone who is in the "Etsy business" - namely, selling such items via the website. http://etsypreneur.com/the-hidden-danger-of-the-internet-opportunity/ 